JOURNAL OF AGRICULTURE AND APPLIED BIOLOGY

2020, Vol. 1, No. 2, $74-85$

http://dx.doi.org/10.11594/jaab.01.02.05

Research Article

\title{
Use of non-chemical methods for the management of southern blight disease of carrot incited by Sclerotium rolfsii
}

\author{
M. Tanbir Rubayet ${ }^{*}$, Farhana Prodhan ${ }^{2}$, M. Shamim Hossain ${ }^{3}$, Minhaz Ahmed ${ }^{4}$, \\ M. Abdullah Al Mamun ${ }^{5}$, M. Khurshed Alam Bhuiyan ${ }^{1}$
}

\begin{abstract}
1Department of Plant Pathology, Faculty of Agriculture, Bangabandhu Sheikh Mujibur Rahman Agricultural University, Gazipur-1706, Bangladesh.

2Department of Agronomy, Faculty of Agriculture, Bangladesh Agricultural University, Mymensingh-2202, Bangladesh.

${ }^{3}$ Department of Entomology, Faculty of Agriculture, Bangabandhu Sheikh Mujibur Rahman Agricultural University, Gazipur-1706, Bangladesh.

${ }^{4}$ Department of Agroforestry \& Environment, Faculty of Agriculture, Bangabandhu Sheikh Mujibur Rahman Agricultural University, Gazipur-1706, Bangladesh.

${ }^{5}$ Department of Agronomy, Faculty of Agriculture, Bangabandhu Sheikh Mujibur Rahman Agricultural University, Gazipur-1706, Bangladesh.
\end{abstract}

Article history:

Submission 30 September 2020

Revised 09 November 2020

Accepted 28 December 2020

\section{Keywords:}

T. harzianum,

S. rolfsii

Soil solarization

Biofumigation

Carrot

*Corresponding author:

E-mail:

tanbir86plp@gmail.com

\begin{abstract}
This experiment was conducted to assess the effect of Trichoderma harzianum, soil solarization, and biofumigant on southern blight disease of carrot incited by Sclerotium rolfsii isolate CS 5. A series of invitro and in-vivo trials laid out to select a virulent isolate of $S$. rolfsii against the carrot variety New Kuroda and evaluated the mustard, cabbage, cauliflower, and broccoli leaf extracts for choosing an effective biofumigant against test pathogen. Mustard was the most effective in inhibiting the radial growth, and sclerotia formation $(80.37$ and $83.37 \%$ ) of S. rolfsii (isolate CS 5) at $40 \%$ level of concentration followed by cabbage leaf extract (62.22 and 68.69\%). On the contrary, a total of 10 isolates of $T$. harzianum were screened against the test pathogen on Potato Dextrose Agar (PDA) medium for choosing a dominant isolate of T. harzianum. The isolate Th- 6 was found as the most active in inhibiting the radial growth (84.44\%) of $S$. rolfsii followed by Th-1 (75.56\%). In the application of T. harzianum, biofumigation, and soil solarization, the treatment appeared to be the most superior in reducing pre- and post-emergence mortality of carrot during secondary field trials. The lowest southern blight disease incidence $(10.77 \%)$, and disease severity $(12.78 \%)$ were found at the same treatment. Subsequently, the yield of carrot was increased $155.18 \%$ which might be due to the reduction of carrot disease as well as the addition of organic materials in the soil.
\end{abstract}




\section{Introduction}

Carrot (Daucus carrota L.) belongs to the family Apiaceae which is cultivating all over the world in spring, summer, and autumn in temperate countries and during winter under the tropical and subtropical regions. It is greatly nutritious as well as delicious vegetable. Additionally, carrot contains ample quantities of nutrients such as carotene and minerals. However, there are several factors attributed to low production of carrot such as climatic conditions, variation in rainfall pattern, and an outbreak of diseases and pests. Among these factors, plant diseases play a major role in yield reduction of carrot. The most important diseases of carrot roots are southern blight, Rhizoctonia crown rot and canker, brown rot, damping off, Phytophthora root rot, Sclerotinia rot, Pythium rot, cottony rot, black rot, scab, bacterial soft rot, root knot and lesion nematodes. The southern blight disease caused by Sclerotium rolfsii, is a serious fungal disease affecting carrot production around the world, especially in tropical and subtropical regions.

This disease does not only reduce yield in the field condition but also deteriorates the yield quality during transportation and storage condition. Furthermore, the infection of $S$. rolfsii generally starts at base point of main stem. As a result, leaf tissues become brown in color and wilted. A white color cushion like mycelial growth appear on the collar region. The root rot gradually progresses downwardly and small spherical tan fungal bodies like sclerotia develop within the damaged root tissues. Moreover, pathogen reduces the crop stand by causing pre- and post-emergence damping off of seedling stage (Ahmed et al., 2019).

On the other hand, $S$. rolfsii is a soil-borne pathogen and overwinters as sclerotia, and mycelia in or on infected plants and debris. Sclerotia can be disseminated through transplant seedlings, water, wind, or any cultural practices. Consequently, soil-borne plant pathogens cause heavy losses to all major crops, leading to reduction in both yield and quality. An effective control of soil-borne plant pathogens are remain a serious challenge to the farmers and home gardeners. Chemical compounds have been used as seed treating fungicide and sometimes effective to control soil-borne pathogens but their exploitation has favored the development of pathogens resistance to fungicides and polluted the environment.

Considering the deleterious effect of synthetic pesticides, alternative measures should be taken for the control of plant pathogenic microorganisms. Therefore, economic and effective eco-friendly control methods are now recommended worldwide.

Now-a-days, organic cultivation such as application of biofumigation, soil solarization, and biological control alone or combinations are demanding issues for safe, low-cost, antitoxic, and effective control of many devastating soil-borne pathogens and pests (Saygl et al., 2019). In biocontrol method, Trichoderma spp. is excellent effective agent against plant diseases (Rubayet \& Bhuiyan, 2012). According to Khattabi et al. (2001), combination of fungicide application (Hymexazol) and T. harzianum is highly effective against $S$. rolfsii. In addition, these procedures not only suppress-the soilborne pathogens of carrot but also control weed, improve soil health and provide essential plant nutrients which could be significantly augmented the crop production. However previous studies showed that, the information about southern blight disease management through non chemical methods are very rare and needs to be precise. Keeping this view, the present study has been undertaken to use nonchemical methods such as biocontrol agent, soil solarization, and biofumigation for the management of southern blight disease of carrot incited by $S$. rolfsii and sustainable crop production.

\section{Materials and Methods Laboratory trials}

A series of laboratory experiments were conducted by using Completely Randomized Design with 3 replications for each treatment. The treatments were leaves extract of mustard, cabbage, cauliflower, and broccoli at four concentrations such as $10,20,30$, and $40 \%$.

\section{Isolation and preservation of $S$. rolfsii iso- lates}

Six isolates of $S$. rolfsii designated as CS 1 to CS 6 were isolated from infected root, and stem 
tissues of potato, tomato, chickpea, chilli, carrot, and eggplant. The specimens which had distinctive symptoms of root rot were selected from the infected fields. The fungal isolates were isolated. Then, the fungal colonies were developed on PDA and identified by following the standard method. The isolates were purified following hyphal tip method and stored in PDA slants at $10^{\circ} \mathrm{C}$.

\section{Cultural characterization of S. rolfsii isolates}

The selected isolates of CS 1 to CS 5 were individually inoculated into three replicated PDA plates using mycelial disks $(\varnothing=5 \mathrm{~mm})$ which taken from 3 days old of PDA cultures. Then, all PDA culture plates were wrapped with parafilm paper tightly and incubated at room temperatures $\left(25 \pm 2{ }^{\circ} \mathrm{C}\right)$ for 7 days. After 7 days of incubation, observation on cultural characteristics such as colony color, colony type, sclerotial population, and sclerotial distribution were recorded. All colonies were whitish, radiate and fluffy and dark brown in color. The sclerotia population density was counted by magnifying glass.

\section{Inoculum preparation of test pathogen}

Inoculum of the $S$. rolfsii isolates were prepared and stored according to the established method (Rubayet \& Bhuiyan, 2016).

\section{Pathogenicity test}

The pathogenicity test of $S$. rolfsii isolates (CS 1- CS 6) were conducted in pot culture on carrot seedling according to the standard method (Rubayet et al., 2017). Nine seeds of carrot were sown in each earthen pot. Three replications for each treatment (CS 1 - CS 6) were maintained and arranged following Completely Randomized Design. Plant disease development was observed regularly and recorded at 10,15, and 21 days after sowing for assessment the effect of the pathogen in causing pre- and post-emergence seedling mortality. The causal agent of pre- and post-emergence seedling mortality was confirmed after re-isolation of the pathogen from un-germinated seeds as well as infected roots (Liton et al., 2019).

\section{Collection, isolation and preservation of $T$. harzianum isolate}

A total of 10 isolates of Trichoderma spp., whereas 7 isolates were isolated from the different crop fields of Gazipur, Bangladesh following the soil dilution plate technique (Sinclair and Dhingra, 1995). And rest of 3 isolates were collected directly from the plant pathology laboratory, Bangabandhu Sheikh Mujibur Rahman Agricultural University, Bangladesh. All the isolated Trichoderma spp. were identified as $T$. harzianum based on the different morphological characteristics like hyphal growth, spore formation and color. The pure culture of T. harzianum was preserved following a regular method for future application (Das et al., 2019).

\section{Screening of Trichoderma spp. isolates against test pathogen}

The in-vitro screening was conducted to evaluate the antagonistic effect of selected 10 isolates of Trichoderma spp. against $S$. rolfsii isolate CS 5 on PDA medium by dual culture technique (Sinclair \& Dhingra, 1995). After 7 days of incubation the inhibition percentage of radial growth of $S$. rolfsii isolate CS 5 was calculated using the following formula (Sundar et al., 1995).

$$
\% \text { inhibition of growth }=\frac{A-B}{A} \times 100
$$

Where, $\mathrm{A}=$ Mycelial development of pathogen in absence of Trichoderma sp. (control) and $\mathrm{B}=$ Mycelial development of pathogen in presence of Trichoderma sp.

\section{Preparation of biocontrol inoculum}

Wheat grain colonized inoculum for the selected isolate of $T$. harzianum isolate Th- 6 was prepared by following the standard procedures (Rubayet \& Bhuiyan, 2016).

\section{Preparation of Brassica spp. leaves extract}

Fresh parts of the test plants such as Brassica oleracea var. capitata (cabbage), Brassica oleracea var. botrytis (cauliflower), Brassica nigra (mustard), and Brassica oleracea var. italica (broccoli) were collected and washed thoroughly with tap water. Then, the extract was 
collected and stored according to the standard method (Rubayet et al., 2018).

\section{In-vitro screening of Brassica spp. against $S$. rolfsii isolate CS 5}

All the plant extracts were tested at 10, 20, 30 , and $40 \%$ concentrations under in-vitro conditions by using food poison technique to study the inhibitory effect of these botanicals against mycelial growth of test pathogen (Rubayet et al., 2018). The radial growth of the test pathogen from culture plate was measured by scale and the number of sclerotia per plate was counted by magnifying glass. The percent inhibition of the radial growth was calculated as described above by Sundar et al. (1995).

\section{Field experiments}

Repeated field experiments were conducted in the research field of Plant Pathology department at Bangabandhu Sheikh Mujibur Rahman Agricultural University, Bangladesh. The experimental site was located at $24^{\circ} 09^{\prime} \mathrm{N}$ latitude and $90^{\circ} 26^{\prime} \mathrm{E}$ longitude center of Madhupur tract (agroecological zone), Gazipur, Bangladesh which characterized by deep to shallow red-brown terrace soils (entisols based on US soil taxonomy), silty clay soil (pH 6.5) with poor nutrients, moderate rainfall, almost clear sunshine, and moderate temperature.

\section{Land preparation and design of experiment}

The cultivated land was prepared by using a tractor driven disc plough, rotavator and harrow. At the meantime, standard dose of organic and chemical fertilizer was applied (Cow dung @ 5 ton ha ${ }^{-1}$, Urea, Triple Super Phosphate (TSP), and Muriate of Potash (MP) @ 200, 100, $175 \mathrm{~kg} \mathrm{ha}^{-1}$ ). The field experiment was designed by using a Randomized Complete Block Design with 8 treatments and 3 replications. The unit plot size was made at $4 \mathrm{~m} \times 3 \mathrm{~m}$ where row to row distance $25 \mathrm{~cm}$.

\section{Treatments of the experiment}

The experiment consisted of eight treatments: $T_{1}=$ Healthy seeds sown in uninoculated soil (Control), $\mathrm{T}_{2}=$ Soil inoculated with test pathogen + Healthy seeds, $\mathrm{T}_{3}=\mathrm{T}_{2}+$ Wheat grain colonized $T$. harzianum inoculum, $\mathrm{T}_{4}=\mathrm{T}_{2}+$ Soil solarization, $\mathrm{T}_{5}=\mathrm{T}_{2}+$ Bio-fumigant, $\mathrm{T}_{6}=\mathrm{T}_{3}+$ Soil solarization, $\mathrm{T}_{7}=\mathrm{T}_{5}+$ Soil solarization, $\mathrm{T}_{8}=\mathrm{T}_{3}+$ Bio-fumigant + Soil solarization.

\section{Treatments application methods}

Among the 8 treatments, 7 treatments were tested in the field under artificially inoculated condition and rest one treatment was tested in uninoculated soil. Inoculum of the selected isolate of test pathogen and biocontrol agent were thoroughly mixed with soil according to design and layout @ $90 \mathrm{~g} \mathrm{~m}^{-2}$, moistened to about 50\% water holding capacity before 21 days carrot seed sowing.

\section{Assessment of solar heat against $S$. rolfsii iso- late CS 5}

Another experiment was accompanied for evaluation of the effect of soil solarization on declining of the soil pathogen population density. The individual plot size was made at $4 \mathrm{~m} \mathrm{x}$ $3 \mathrm{~m}$ and arranged in Randomized Complete Block Design with 3 replications. The selected treatments $\left(\mathrm{T}_{4}-\mathrm{T}_{8}\right)$ were inoculated with the test pathogen. Then, the plots were kept 3 weeks within sufficient soil moisture and undisturbed for proper growth of the test pathogen population. After that, each plot in term of the treatment was covered with $100 \mu \mathrm{m}$ thickness transparent polyethylene sheet to rise soil temperature for four weeks before carrot seeds sowing.

\section{Assessment of biofumigation against $S$. rolfsii isolate CS 5}

The Brassica nigra (mustard) was grown for determination of biofumigant effect against test pathogen. When the mustard crop was about 4 inches height, it was cut and incorporated into the soil properly then either covered or exposed according to the treatment with polythene sheet for 5 weeks before carrot seeds sowing.

\section{Collection of seeds}

Carrot seed sample variety New Kuroda was collected from open market, Dhaka, Bangladesh.

\section{Seed sowing}

Seeds were soaked for 24 hours to facilitate the germination before sowing. Then, seeds 
were sown in lines uniformly by hand @ $3 \mathrm{~kg}$ ha $^{-1}$. After seeds sowing the soil was mulched with rice straw for preservation soil moisture. Mulches were removed after 6 days when seeds were started to germinate. Weeding, mulching, and irrigation were done in the experimental field whenever necessary.

\section{Data recording and analysis}

The typical symptom of southern blight was observed and data recorded from growing to harvesting period. Data recorded on germination, number of healthy plants and number of infected plants. Forty-five plants in each plot were randomly selected and uprooted carefully from soil, washed with running water then checked individually and disease severity was rated as $0-4$ scale in which $0=$ No symptoms, $1=1-25 \%, 2=26-50 \%, 51-75 \%$ and $4=76-100 \%$ of carrot tap root covered with lesions. The disease incidence and disease severity were assessed by the following formula (Rahman et al., 2013; Razaq et al., 2015).

DI $=\frac{\text { No. of infected plants }}{\text { Total No. of plants assessed }} \times 100$

PDI $=\frac{\text { Summation of all ratings }}{\text { Total No. of rating } \times \text { Max. disease grade }(4)} \times 100$

Total yield $\left(\right.$ ton $\left.\mathrm{ha}^{-1}\right)=\frac{\text { Yield per plot }(\mathrm{kg})}{\text { Area of plot }\left(\mathrm{m}^{2}\right) \times 1000(\mathrm{~kg})} \times 10000 \mathrm{~m}^{2}$

\section{Data analysis}

Statistically, data were analyzed using the Statistix 10 computer program after proper transformation whenever it was necessary. The treatment means were compared following Duncan's Multiple Range Test $(\alpha=0.05)$.

\section{Results and Discussion}

Isolation and cultural characterization of $S$. rolfsii isolates

The six isolates of $S$. rolfsii were isolated from the different crops field at Gazipur district, Bangladesh (Table 1). Mycelium of all the isolates were found whitish fluffy with radiate growth on PDA. Sclerotia of relatively uniform size produced on mycelium. Sclerotia were round and white when immature and then became dark brown at mature stage. Moreover, a mature sclerotium resembled mustard seedlike. All the isolates produced large number of small sclerotia which ranged from 402-585. The highest number of sclerotia formation in culture plate was observed in isolate CS 5 (585) and the lowest number was recorded in isolate CS 4 (402) (Table 1).

Table 1. Cultural characterization of S. rolfsii isolates

\begin{tabular}{|c|c|c|c|c|c|}
\hline $\begin{array}{l}\text { Iso- } \\
\text { lates }\end{array}$ & Sources & Colony type & $\begin{array}{l}\text { No. of scle- } \\
\text { rotia/plate }\end{array}$ & $\begin{array}{l}\text { Pattern of sclerotia for- } \\
\text { mation }\end{array}$ & $\begin{array}{l}\text { Sclerotia } \\
\text { color }\end{array}$ \\
\hline CS 1 & Chilli & $\begin{array}{l}\text { Whitish, Radiate } \\
\text { and Fluffy }\end{array}$ & 463 & $\begin{array}{l}\text { Spread all over the plate, } \\
\text { preferably in margin side }\end{array}$ & Dark brown \\
\hline CS 2 & Potato & $\begin{array}{l}\text { Whitish, Radiate } \\
\text { and very Fluffy }\end{array}$ & 552 & Spread all over the plate & Dark brown \\
\hline CS 3 & Tomato & $\begin{array}{l}\text { Whitish, Radiate } \\
\text { and Fluffy }\end{array}$ & 518 & $\begin{array}{l}\text { spread all over the plate, } \\
\text { preferably in margin side }\end{array}$ & Dark brown \\
\hline $\operatorname{CS} 4$ & Eggplant & $\begin{array}{l}\text { Whitish, Radiate } \\
\text { and Fluffy }\end{array}$ & 402 & Mostly in the periphery & Dark brown \\
\hline CS 5 & Carrot & $\begin{array}{l}\text { Whitish, Radiate } \\
\text { and Fluffy }\end{array}$ & 585 & Mostly in the periphery & Dark brown \\
\hline CS 6 & Chickpea & $\begin{array}{l}\text { Whitish, Radiate } \\
\text { and very Fluffy }\end{array}$ & 428 & $\begin{array}{l}\text { Spread all over the plate, } \\
\text { preferably in margin side }\end{array}$ & Dark brown \\
\hline
\end{tabular}




\section{Pathogenicity test of S. rolfsii isolates}

Total six selected isolates of $S$. rolfsii were evaluated in the pot culture experiment for selecting the most virulent isolate causing seedlings mortality of carrot. All the tested isolates of $S$. rolfsii were found highly pathogenic against carrot seedlings causing 37.50 to $100 \%$ seedling mortality. The highest $100 \%$ seedling mortality for $S$. rolfsii was observed with the isolate CS 5 followed by the isolate CS 2 $(81.25 \%)$ and CS $3(68.75 \%)$ (Table 2). Preand post- emergence mortality of seedling caused by $S$. rolfsii was also reported by several studies (Akhter et al., 2015; Rubayet et al., 2017; Ahmed et al., 2019). The result of this present study was also agreed with the aforesaid studies.

Table 2. Pathogenicity test of S. rolfsii isolates against carrot seedlings

\begin{tabular}{cccc}
\hline Isolates of S. rolfsii & \multicolumn{2}{c}{ Seedling mortality (\%) } & \multirow{2}{*}{$\begin{array}{c}\text { Total mortality } \\
\text { (\%) }\end{array}$} \\
\cline { 2 - 3 } & Pre-emergence & Post- emergence & $62.50 \mathrm{bc}^{1}$ \\
CS 1 & 31.25 & 31.25 & $81.25 \mathrm{ab}$ \\
CS 2 & 62.50 & 18.75 & $68.75 \mathrm{~b}$ \\
CS 3 & 43.75 & 25.00 & $37.50 \mathrm{c}$ \\
CS 4 & 25.00 & 12.50 & $100.00 \mathrm{a}$ \\
CS 5 & 68.75 & 31.25 & $56.25 \mathrm{bc}$ \\
CS 6 & 37.50 & 18.75 & \\
\hline
\end{tabular}

${ }^{1}$ Means within same column followed by common letter(s) are not significantly different $(\alpha=0.05)$

Screening of Trichoderma spp. against test pathogen

Ten isolates of Trichoderma spp. were tested against the isolate of CS 5 of $S$. rolfsii on PDA medium by dual culture technique. All the tested isolates of Trichoderma spp. showed more than $50 \%$ inhibition of the radial growth of the test pathogen over control treatment. Among the tested isolates, Th- 6 showed the highest $(84.44 \%)$ reduction of the radial growth against $S$. rolfsii followed by Th-1 (75.56\%). On the other hands, the lowest radial growth inhibition of $S$. rolfsii was observed by the isolate T-17 (50.00\%) (Table 3). Similarly, significant reduction of mycelial growth of $S$. rolfsii in presence of $T$. harzianum was also reported by several previous studies (Bell et al., 1982; Rubayet et al., 2011; Liton et al., 2019; Simi et al., 2019).

Table 3. Screening of Trichoderma spp. against S. rolfsii isolate CS 5 in dual culture

\begin{tabular}{ccc}
\hline Trichoderma isolates & Percent of inhibition & Bell's scale $^{1}$ \\
\hline Th-6 & 84.44 & $\mathrm{R}_{1}$ \\
Th-1 & 75.56 & $\mathrm{R}_{1}$ \\
Th-3 & 71.11 & $\mathrm{R}_{2}$ \\
Th-5 & 65.56 & $\mathrm{R}_{2}$ \\
Th-4 & 64.44 & $\mathrm{R}_{2}$ \\
Th-2 & 63.33 & $\mathrm{R}_{2}$ \\
Th-8 & 62.22 & $\mathrm{R}_{2}$ \\
Th-9 & 61.11 & $\mathrm{R}_{2}$ \\
Th-7 & 58.89 & $\mathrm{R}_{2}$ \\
Th-10 & 50.00 & $\mathrm{R}_{3}$ \\
\hline \multicolumn{3}{c}{$90.00 \mathrm{~mm}$} \\
\hline
\end{tabular}

${ }^{1}$ The lysed mycelium of $S$. rolfsii by Trichoderma sp. was scoring by the modified Bell's scale (Bell et al., 1982), $\mathrm{R}_{1} \geq 75 \%$ overgrowth of Trichoderma sp., $\mathrm{R}_{2} \geq 55 \%$ overgrowth of Trichoderma sp., $\mathrm{R}_{3} \geq 50 \%$ of Trichoderma sp., $\mathrm{R}_{4} \leq 50 \%$ and blocked at the point of contact, and $\mathrm{R}_{5}=$ Pathogen overgrowth against antagonist. 
Effect of Brassica spp. leaves extract on $S$. rolfsii isolate $\mathrm{CS} 5$

The highest $80.37 \%$ inhibition of mycelial growth of $S$. rolfsii isolate CS 5 was observed at the highest $40 \%$ concentration of mustard leaves extract followed by $62.59 \%$ inhibition at $30 \%$ concentration. Additionally, cabbage $62.22 \%$, cauliflower $55.56 \%$, broccoli leaves extract $50.37 \%$ inhibition of mycelium radial growth of $S$. rolfsii isolate CS 5 at $40 \%$ concentration level. On the other hands, the lowest inhibition of $S$. rolfsii isolate CS 5 was recorded $17.41 \%$ at $10 \%$ concentration level of broccoli leaves extract (Table 4). In case of sclerotia formation of test pathogen, the highest $83.37 \%$ inhibition were achieved at $40 \%$ mustard leaves extract followed by $68.69 \%$ and $60.74 \%$ cab- bage and broccoli leaves extract at same concentration. Cauliflower leaves extract was appeared ineffective in reducing sclerotia formation. However, the highest $83.37 \%$ reduction of sclerotia formation of $S$. rolfsii isolate CS 5 was observed at the highest $40 \%$ concentration of mustard leaves extract which indicated that mustard leaves extract was significantly superior to all others leaves extract in reducing the radial colony growth and sclerotia formation. Significant inhibition in radial growth and sclerotia formation were also observed on cabbage and broccoli leaves extract but statistically inferior than mustard leaves extract. Similar result was also reported in reduction of radial growth of $S$. rolfsii in various plant extracts by Dwivedi and Prasad, 2016.

Table 4. Preliminary laboratory evaluation of leaves extract in inhibition of radial growth and sclerotia formation of test pathogen

\begin{tabular}{lccc}
\hline \multirow{2}{*}{ Leaves extract } & \multirow{2}{*}{ Concentration (\%) } & \multicolumn{2}{c}{ \% inhibition } \\
\cline { 2 - 4 } Mustard & 10 & Radial growth & Sclerotia formation \\
\hline & 20 & $42.22{\mathrm{f}-\mathrm{h}^{1}}^{2}$ & $39.87 \mathrm{i}$ \\
& 30 & $62.59 \mathrm{~b}$ & $48.42 \mathrm{~g}$ \\
Cabbage & 40 & $80.37 \mathrm{a}$ & $65.32 \mathrm{c}$ \\
& 10 & $18.89 \mathrm{j}$ & $83.37 \mathrm{a}$ \\
& 20 & $30.37 \mathrm{gh}$ & $24.58 \mathrm{k}$ \\
Cauliflower & 30 & $49.26 \mathrm{~cd}$ & $35.76 \mathrm{j}$ \\
& 40 & $62.22 \mathrm{~b}$ & $52.73 \mathrm{f}$ \\
& 10 & $17.41 \mathrm{j}$ & $68.69 \mathrm{~b}$ \\
Broccoli & 30 & $26.30 \mathrm{hi}$ & $21.62 \mathrm{l}$ \\
& 40 & $39.63 \mathrm{ef}$ & $33.94 \mathrm{j}$ \\
& 10 & $55.56 \mathrm{bc}$ & $44.31 \mathrm{~h}$ \\
& 20 & $18.15 \mathrm{j}$ & $57.58 \mathrm{e}$ \\
Control & 30 & $28.52 \mathrm{~h}$ & $25.19 \mathrm{k}$ \\
& 40 & $37.41 \mathrm{e}-\mathrm{g}$ & $35.62 \mathrm{j}$ \\
& $90 \mathrm{~mm}$ & $50.37 \mathrm{~cd}$ & $42.36 \mathrm{~h}$ \\
& & & $60.74 \mathrm{~d}$ \\
\hline
\end{tabular}

${ }^{1}$ Means within same column followed by common letter(s) are not significantly different $(\alpha=0.05)$

Integrated effect of biofumigant, soil solarization and bio-agent on southern blight

Effect on pre-and post-emergence mortality

Significantly, the highest pre-and postemergence seedling mortality 32.31 and $22.56 \%$ were recorded in the treatment $\mathrm{T}_{2}$ where seeds were sown in the inoculated soil without any other amendment, followed by treatment $\mathrm{T}_{1}$ (control) where seeds were sown in uninoculated field. On the contrary, the lowest total seedling mortality in comparison with all other treatments were observed at treatment $\mathrm{T}_{8}(16.41 \%)$ followed by $\mathrm{T}_{6}(21.54 \%), \mathrm{T}_{7}$ (25.13\%), and $\mathrm{T}_{5}(27.18 \%)$ (Table 5). Among 
the different treatments including biofumigation, soil solarization and biocontrol agent either individual or in combination, the treatment $\mathrm{T}_{8}$ was appeared to be the most superior in reducing the pre-and post-emergence mortality of carrot caused by $S$. rolfsii isolate CS 5 . The treatment performance of $\mathrm{T}_{6}, \mathrm{~T}_{7}$, and $\mathrm{T}_{5}$ were identical with $\mathrm{T}_{8}$ in term of reducing total seedling mortality. The results of the current study suggest the superiority of integrated approach for management of $S$. rolfsii isolate CS 5 either individual treatment by biofumigant and/soil solarization or biocontrol agent. Seedling mortality and other seedling diseases of different crops were controlled through the integration of antagonist with diverse organic amendments by different studies (Rahman et al., 2012; Rubayet et al., 2018) which support the findings of this present study.

Table 5. Effect of integrated use of soil solarization, biofumigation and biocontrol agent on carrot seedling mortality caused by test pathogen

\begin{tabular}{cccc}
\hline Treatments & \multicolumn{3}{c}{ Mortality \% } \\
\cline { 2 - 4 } & Pre-emergence & Post-emergence & Total \\
\hline $\mathrm{T}_{1}$ & 29.74 & 15.38 & $45.13 \mathrm{~b}$ \\
$\mathrm{~T}_{2}$ & 32.31 & 22.56 & $54.87 \mathrm{a}$ \\
$\mathrm{T}_{3}$ & 29.23 & 8.21 & $37.44 \mathrm{c}^{1}$ \\
$\mathrm{~T}_{4}$ & 23.59 & 8.21 & $31.79 \mathrm{~cd}$ \\
$\mathrm{~T}_{5}$ & 20.00 & 7.18 & $27.18 \mathrm{de}$ \\
$\mathrm{T}_{6}$ & 15.90 & 5.64 & $21.54 \mathrm{ef}$ \\
$\mathrm{T}_{7}$ & 18.46 & 6.67 & $25.13 \mathrm{e}$ \\
$\mathrm{T}_{8}$ & 13.33 & 3.08 & $16.41 \mathrm{f}$ \\
$\mathrm{CV}$ & & & 10.38 \\
\hline
\end{tabular}

${ }^{1}$ Means within same column followed by common letter(s) are not significantly different $(\alpha=0.05)$

\section{Effect on disease incidence and severity}

The disease incidence and severity of southern blight of carrot were significantly influenced by single or combination of biofumigant, biocontrol agent, and solarized soil (Figure 1). The lowest disease incidence $(10.77 \%)$ and severity (12.78\%) as well as maximum reduction (75.86 and $78.30 \%$ ) of southern blight disease of carrot were found in $\mathrm{T}_{8}$ followed by $\mathrm{T}_{6}$ (Table 6). On the contrary, significantly highest disease incidence $(74.87 \%)$ and severity
(79.44\%) of southern blight disease of carrot were observed in the $\mathrm{T}_{2}$ treatment where seeds were sown in the test pathogen inoculated soil without any other amendment. The results indicated that all the treatments except $\mathrm{T}_{1}$ and $\mathrm{T}_{2}$ were significantly effective in plummeting disease incidence and severity of carrot seedlings which is also agreed with several previous studies in different crops by Rahman et al., 2013; Chandel \& Sharma, 2014; Rubayet et al., 2018. 
MT Rubayet et al., 2020 / Use of non-chemical methods for the management of southern blight disease

Table 6. Effect of integrated use of soil solarization, biofumigation and biocontrol agent on incidence and severity of southern blight disease in carrot under open field condition

\begin{tabular}{ccccc}
\hline Treatments & $\begin{array}{c}\text { \% disease } \\
\text { incidence }\end{array}$ & $\begin{array}{c}\text { \% disease incidence } \\
\text { reduction/ increase } \\
(-) \text { over control }\end{array}$ & $\begin{array}{c}\text { \% disease } \\
\text { severity }\end{array}$ & $\begin{array}{c}\text { \% disease severity reduc- } \\
\text { tion/ increase (-) over } \\
\text { control }\end{array}$ \\
\hline $\mathrm{T}_{1}$ & $44.62 \mathrm{~b}$ & - & $58.89 \mathrm{~b}$ & - \\
$\mathrm{T}_{2}$ & $74.87 \mathrm{a}$ & -67.79 & $79.44 \mathrm{a}$ & -34.90 \\
$\mathrm{~T}_{3}$ & $33.33 \mathrm{c}$ & 25.30 & $47.78 \mathrm{c}$ & 18.87 \\
$\mathrm{~T}_{4}$ & $28.21 \mathrm{~cd}$ & 36.78 & $39.44 \mathrm{~cd}^{1}$ & 33.03 \\
$\mathrm{~T}_{5}$ & $25.64 \mathrm{~cd}$ & 42.54 & $31.11 \mathrm{de}$ & 47.17 \\
$\mathrm{~T}_{6}$ & $14.36 \mathrm{ef}$ & 67.82 & $15.19 \mathrm{fg}$ & 74.21 \\
$\mathrm{~T}_{7}$ & $20.51 \mathrm{de}$ & 54.03 & $24.44 \mathrm{ef}$ & 58.50 \\
$\mathrm{~T}_{8}$ & $10.77 \mathrm{f}$ & 75.86 & $12.78 \mathrm{~g}$ & 78.30 \\
\hline $\mathrm{CV}$ & 14.10 & - & 15.28 & - \\
\hline
\end{tabular}

1Means within same column followed by common letter(s) are not significantly different $(\alpha=0.05)$

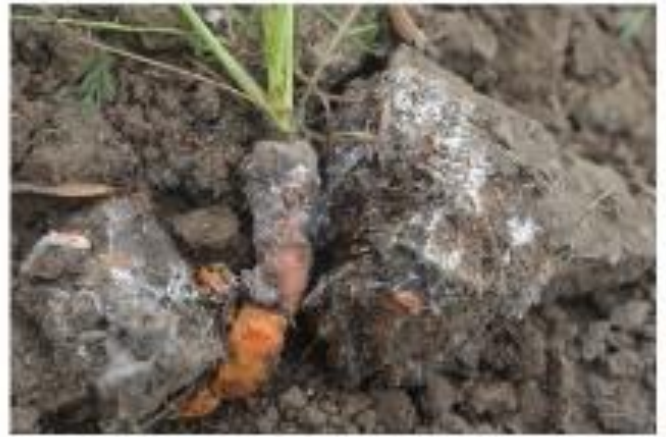

A

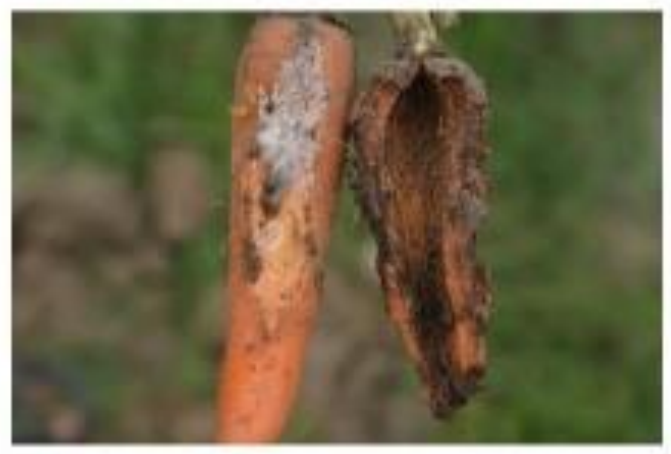

C

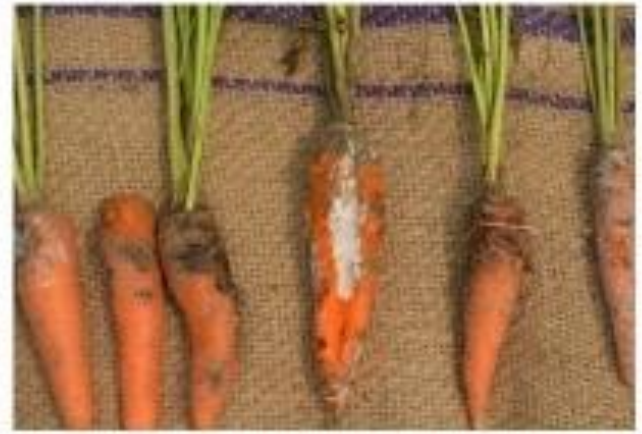

B

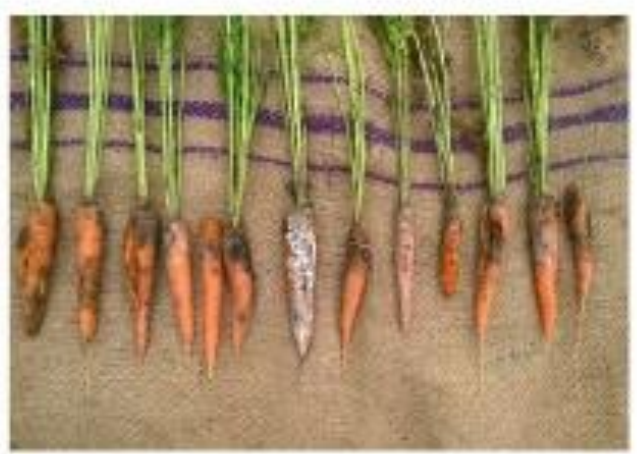

D

Figure 1. Southern blight disease of carrot caused by S. rolfsii isolate CS 5 (A-D)

Effect on the yield of carrot in field

In this experiment, the application of biofumigant, soil solarization and bio-agent not only compacted the disease development caused by
S. rolfsii isolate CS 5 but also significantly improved the yield of carrot (Table 7). The highest 41.11 ton ha-1 yield was recorded in the plot where soil solarized by polythene mulch, used 
mustard as biofumigant and wheat grain colonized $T$. harzianum in the treatment $\mathrm{T}_{8}$ followed by $\mathrm{T}_{6}$ and $\mathrm{T}_{7}$. On the contrary, significantly the lowest yield in control plot $\mathrm{T}_{1}(16.11$ ton $\mathrm{ha}^{-1}$ ) was recorded where seed sown uninoculated field without any other amendment and in the treatment $\mathrm{T}_{2}$ (11.67 ton ha-1) where seeds sown in test pathogen inoculated field without any other amendment. Moreover, the maximum yield (155.18\%) was increased in treatment $\mathrm{T}_{8}$ followed by $\mathrm{T}_{6}$. On the other hands, around $27.56 \%$ yield was declined in treatment $\mathrm{T}_{2}$ because of hefty pathogen population density as well as devastating disease infestation.

Table 7. Effect of integrated use of soil solarization, biofumigation and biocontrol agent on yield response in carrot under open field condition

\begin{tabular}{ccc}
\hline Treatments & Yield (ton ha $\left.{ }^{-1}\right)$ & \% yield increase/ reduction (-) over control \\
\hline $\mathrm{T}_{1}$ & $16.11 \mathrm{ef}^{1}$ & - \\
$\mathrm{T}_{2}$ & $11.67 \mathrm{f}$ & -27.56 \\
$\mathrm{~T}_{3}$ & $22.22 \mathrm{de}$ & 37.93 \\
$\mathrm{~T}_{4}$ & $25.56 \mathrm{~cd}$ & 58.66 \\
$\mathrm{~T}_{5}$ & $26.67 \mathrm{~cd}$ & 65.55 \\
$\mathrm{~T}_{6}$ & $33.89 \mathrm{~b}$ & 110.37 \\
$\mathrm{~T}_{7}$ & $31.11 \mathrm{bc}$ & 93.11 \\
$\mathrm{~T}_{8}$ & $41.11 \mathrm{a}$ & 155.18 \\
\hline $\mathrm{CV}$ & 18.86 & - \\
\hline
\end{tabular}

${ }^{1}$ Means within same column followed by common letter(s) are not significantly different $(\alpha=0.05)$

Therefore, biofumigation is used as a means to control many soil-borne diseases by biocidal compounds (mainly isothiocyanates) released from glucosinolates in mustard seed meal which is hydrolyzed during degradation in soil (Shaban et al., 2011). In addition, soil solarization practice can rise soil temperature to such level that may kill many disease causing pathogens such as nematodes, fungi, bacteria and weed seeds and seedlings. It also helps to disintegrate the organic materials in the soil and upsurges the amount of soluble nutrients such as Ammonium $\left(\mathrm{NH}_{4}^{+}\right)$, Nitrate ( $\left.\mathrm{NO}^{3-}\right)$, Potassium $(\mathrm{K})$, Calcium $(\mathrm{Ca})$, and Magnesium $(\mathrm{Mg})$ in the soil which are energetic for the growth and development of plants. Accordingly, several volatile bio-toxic compounds are discharged when organic matter is heated and they may expand the biocidal activity in soil. It has been found that plants grow quicker when grown in solarized soil. Integrated use of solarization with biofumigation and compost amendments the re-introduction of biocontrol agents such as Trichoderma spp. and Bacillus spp. may be more effective than either treatment alone in controlling soil-borne disease. Population density of these two microbial antagonists increase relatively higher than other microorganisms under the solarized soil. On the other hands, $T$. harzianum produces a large number of chemical substances to solubilize rock Phosphate $\left(\mathrm{PO}_{4}{ }^{3-}\right)$, Cupper ions $\left(\mathrm{Cu}^{2+}\right)$, Manganese ions $\left(\mathrm{Mn}^{4+}\right)$ and Zinc $\left(\mathrm{Zn}^{2+}\right)$ increase iron (Fe) availability in the soil (Altomare et al., 1999). Thus, the solubilization and chelating abilities of $T$. harzianum may also influenced the cumulative yield of carrot. The findings of the present investigation was in good agreement with the previous studies (Arefin et al., 2019; Rahman et al., 2020a; Rahman et al., 2020b).

\section{Conclusion}

The study revealed that $T$. harzianum isolate Th- 6 as biocontrol agent and mustard leaves extract as natural biofumigant appeared highly effective in terms of inhibiting the radial growth and sclerotia formation of $S$. rolfsii isolate CS 5 in in-vitro trials. In the field condition, integrated use of biofumigation, solarization, 
and biocontrol agent provided the active control measure against southern blight of carrot caused by $S$. rolfsii isolate CS 5 .

\section{Acknowledgment}

The authors express their gratefulness to the Research Management Committee (RMC), Bangabandhu Sheikh Mujibur Rahman Agricultural University, Gazipur 1706, Bangladesh for providing financial support to accomplish this research work.

\section{Conflict of Interest}

Authors declare that there is no conflict of interest.

\section{Authors Contribution}

M. T. Rubayet and M. K. A. Bhuiyan conceived the presented idea. They also conducted both laboratory and field experiments and recorded the observations accurately. F. Prodhan performed the computations and made the draft manuscript. M. S. Hossain, M. Ahmed and M. A. A. Mamun verified the statistical data analysis and updated the references. Finally, all authors read the manuscript carefully and approved the final version.

\section{References}

Ahmed, M. U., Bhuiyan, M. K. A., Hossain, M. M., Rubayet, M. T., \& Khaliq, Q. A. (2019). Efficacy of chitosan and bio-agent in controlling southern blight disease of carrot caused by Sclerotium rolfsii and improvement the crop production. Research in Agriculture and Veterinary Science, 3(3), 113-125.

http://jomardpublishing.com/Upload-

Files/Files/journals/RV/V3N3/Ahmed.pdf.

Akhter, W., Bhuiyan, M. K. A., Sultana, F., \& Hossain, M. M. (2015). Integrated effect of microbial antagonist, organic amendment and fungicide in controlling seedling mortality (Rhizoctonia solani) and improving yield in pea (Pisum sativum L.). Comptes Rendus Biologies, 338 (1), 21-28.

https://doi.org/10.1016/i.crvi.2014.10.003

Altomare, C., Norvell, W. A., Bjorkman, T., \& Harman, G. C. (1999). Solubilization of phosphates and micronutrients by the plant- growth promoting and biocontrol fungus Trichoderma harzianum Rifai 1295-22. Applied and Environmental Microbiology, 65(7), 2926-2933.
https://doi.org/10.1128/AEM.65.7.29262933.1999

Arefin, M. N., Bhuiyan, M. K. A., \& Rubayet, M. T. (2019). Integrated use of fungicide, plant extract and bioagent for management of Alternaria blight disease of Radish (Raphanus sativus L.) and quality seed production. Research in Agriculture and Veterinary Science, 3(1), 10-21. http://jomardpublishing.com/UploadFiles/Files/iournals/RV/V3N1/Nazmul\%20Are$\underline{\text { fin } \% 20 \text { et } \% 20 \text { al.pdf. }}$.

Bell, D. K., Wells, H. D., \& Markham, C. R. (1982). In vitro antagonism of Trichoderma species against six fungal plant pathogens. Phytopathological, 72, 379382. https://doi.org/10.1094/Phyto-72-379.

Chandel, S., \& Sharma, S. (2014). Botanicals, biofumigants and antagonists application in managing stem rot disease caused by Rhizoctonia solani Kuhn in carnation. Journal of Biopesticides, 7(1), 3-10.

http://www.jbiopest.com/users/LW8/efiles/vol 7 1 3-10.pdf.

Das, I. R., Bhuiyan, M. K. A., Jannat, R., Kayesh, E., Rubayet, M. T., \& Arefin, M. N. (2019). Effect of bio-fortified compost in controlling soil-borne diseases of lentil (Lens culinaris L.) and enhance the crop growth and yield. Advances in Biology \& Earth Sciences, 4(2), 93-106. http://jomardpublishing.com/UploadFiles/Files/iournals/ABES/V4N2/Das\%20et\%20al.pdf.

Dwivedi, S. K., \& Prasad, G. (2016). Integrated management of Sclerotium rolfsii: an overview. European Journal of Biomedical and Pharmaceutical Sciences, 3(11), 137-146. https://www.ejbps.com/ejbps/abstract_id/1846.

Khattabi, N., Ezzahiri, B., Louali, L., \& Oihabi, A. (2001). Effect of fungicides and Trichoderma harzianum on sclerotia of Sclerotium rolfsii. Phytopathologia Mediterranea, 40(2), 43-148.

https://doi.org/10.14601/Phytopathol_Mediterr1597.

Liton, M. J. A., Bhuiyan, M. K. A., Jannat, R., Ahmed, J. U., Rahman, M. T., \& Rubayet, M. T. (2019). Efficacy of Trichoderma-fortified compost in controlling soilborne diseases of bush bean (Phaseolus vulgaris L.) and sustainable crop production. Advances in Agricultural Science, 7(2), 123-136. https://aaasjournal.org/submission/index.php/aaas/article/view/171/83

Rahman, M. M., Ali, M. A., Ahmad, M. U., \& Dey, T. K. (2013). Effect of tuber-borne inoculum of Rhizoctonia solani on the development of stem canker 
and black scurf of potato. Bangladesh Journal of Plant Pathology, 29(1\&2), 29-32.

Rahman, M. T., Rubayet, M. T., \& Bhuiyan, M. K. A. (2020a). Integrated management of rhizoctonia root rot disease of soybean caused by Rhizoctonia solani. Nippon Journal of Environmental Science, 1(7), 1-10. https://doi.org/10.46266/njes.1018.

Rahman, M. T., Rubayet, M. T., Khan, A. A., \& Bhuiyan, M. K. A. (2020b). Integrated management of fusarium root rot and wilt disease of soybean caused by Fusarium oxysporum. International Journal of Biosciences, 17(2), 83-96.

http://dx.doi.org/10.12692/ijb/17.2.83-96.

Rahman, Z., Mafuzul Haque, A. H. M., Zaman, M. A., Amin, M. F., \& Das, A. K. (2012). Efficacy of two fungicides and two botanicals to control foot and root rot disease (Sclerotium rolfsii) of cowpea. Bangladesh Journal of Plant Pathology, 28(1\&2): 29-32.

Razaq, M., Rab, A., Alam, H., Salahuddin, Saud, S., \& Ahmad, Z. (2015). Effect of potash levels and plant density on potato yield. Journal of Biology, Agriculture and Healthcare, 5(13), 54-62.

Rubayet, M. T., \& Bhuiyan, M. K. A. (2016). Integrated management of stem rot of potato caused by Sclerotium rolfsii. Bangladesh Journal of Plant Pathology, 32(1\&2), 7-14.

Rubayet, M. T., Bhuiyan, M. K. A., \& Akanda, M. A. M. (2011). Effect of fungicides, organic amendments and antagonist on in vitro growth of Sclerotium rolfsii. Bangladesh Journal of Plant Pathology, 27(1 \&2), 47-52.

Rubayet, M. T., Bhuiyan, M. K. A., \& Hossain, M. M. (2017). Effect of soil solarization and biofumigation on stem rot disease of potato caused by Sclerotium rolfsii. Annals of Bangladesh Agriculture, 21(1\&2), 49-59. https://bsmrau.edu.bd/aba/wp-content/uploads/sites/320/2019/07/Manuscript$\underline{\text { 5.pdf. }}$
Rubayet, M. T., Bhuiyan, M. K. A., Jannat, R., Masum, M. M. I., \& Hossain, M. M. (2018). Effect of biofumigation and soil solarization on stem canker and black scurf diseases of potato (Solanum tuberosum L.) caused by Rhizoctonia solani isolate PR2. Advances in Agricultural Science, 6(3), 33-48. http://aaasjournal.org/effect-of-biofumigation-and-soil-solarization-on-stem-canker-and-black-scurf-diseases-ofpotato-solanum-tuberosum-l-caused-by-rhizoctonia-solani-isolate-pr2/.

Rubayet, T., \& Bhuiyan, M. K. A. (2012). Compatibility of an Isolate of Trichoderma harzianum with fungicides and organic amendments. Bangladesh Journal of Plant Pathology, 28(1 \&2), 63-66.

Saygı, S., Türkkan, M., Erper, I. (2019). Usage possibilities of biofumigation in controlling of soil-borne plant pathogenic fungi. Turkish Journal of Agriculture Food Science and Technology, 7(9), 1245-1248. https://doi.org/10.24925/turjaf.v7i9.1245$\underline{1248.1569}$.

Shaban, W. I., El-Barougy, E., \& Zian, A. H. (2011). Control of lupine Fusarium wilt by biofumigation with mustard and canola seed meal. Tunisian Journal of Protection, 6(2), 87-98.

Simi, S. A., Jannat, R., Rubayet, M. T., \& Bhuiyan, M. K. A. (2019). Efficacy of bio-fortified compost in controlling anthracnose disease of chilli caused by Colletotrichum capsici and improvement the crop production. Scholars Academic Journal of Bioscience, 7(12), 482-489. https://doi.org/10.36347/SAJB.2019.v07i12.005.

Sinclair, J., \& Dhingra, O. (1995). Basic Plant Pathology Methods (2nd ed.). Boca Raton: CRC Press. https://doi.org/10.1201/9781315138138.

Sundar, A. R., Das, N. D., \& Krishnaveni, D. (1995). In vitro antagonism of Trichoderma spp. against two fungal pathogens of castor. Indian Journal of Plant Protection, 23(2), 152-155. 